\title{
The Devil is in The Disclosure: The Role of R. V. STINCHCOMBE IN ESTABLISHING APPROPRIATE Disclosure Rules fOR Administrative Tribunals
}

\author{
ALICE WOOLLEY ${ }^{*}$
}

This article examines disclosure rules for administrative tribunals in light of the decision of the Supreme Court of Canada in R. v. Stinchcombe. The pre-and post-Stinchcombe administrative law cases relating to document disclosure are discussed with a view to determining the effect that Stinchcombe has had on the administrative process. It is argued that Stinchcombe has had a significant impact on judicial and legislative opinions regarding the importance of document disclosure on procedural fairness in administrative decisionmaking. However, the application of Stinchcombe in administrative law cases has been neither complete nor unanimous. The appropriateness of the principles of Stinchcombe in the context of proceedings before an administrative tribunal are discussed with specific regard to proceedings before the Alberta Energy and Utilities Board.
L'auteur de cet article examine les règles de divulgation des tribunaux administratifs $\dot{a}$ la lumière de la décision de la Cour suprème du Canada dans l'affaire R. c. Stinchcombe. Les cas de jurisprudence avant et après l'affaire Stinchcombe relatis à la communication de documents y sont discutés dans le but de déterminer l'incidence de l'affaire Stinchcombe sur la procédure administrative. On estime que l'affaire Stinchcombe a eu un impact considérable sur les avis judiciaires et législatifs en ce qui concerne l'importance de communiquer pour assurer l'impartialité des décisions administratives. Cependant, la jurisprudence du droit administratif n'a pas appliqué l'affaire Stinchcombe ni entièrement ni $\dot{a}$ l'unanimité. La pertinence des principes de l'affaire Stinchcombe dans le contexte des poursuites devant un tribunal administratif y est discutée et une attention spéciale est accordée aux poursuites devant la Alberla Energy and Utilities Board.

\section{TABLE OF CONTENTS}

I. INTRODUCTION $\ldots \ldots \ldots \ldots \ldots \ldots \ldots \ldots \ldots \ldots \ldots \ldots$

II. DOCUMENT DISClOSURE AND PROCEDURAL

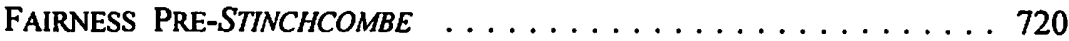

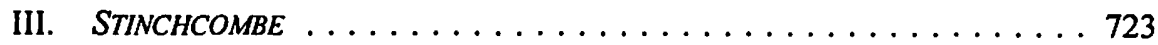

IV. APPLICATION OF STINCHCOMBE IN

AdMINISTRATIVE LaW ProceEdings $\ldots \ldots \ldots \ldots \ldots \ldots \ldots 726$

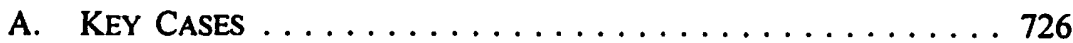

B. Significance of THE CASES $\ldots \ldots \ldots \ldots \ldots \ldots \ldots 734$

V. DOCUMENT Disclosure IN PROCEedings before the

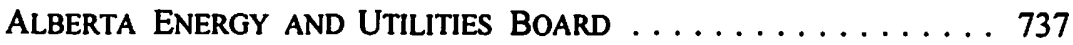

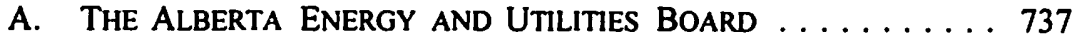

B. DOCUMENT DISClOSURE ISSUES RAISED BY

PROCEEDING BEFORE THE ALBERTA ENERGY

AND UTILITIES BOARD . . . . . . . . . . . . . 738

C. THE AlBERTA ENERGY AND Utilities BoARD'S

Position ON DOCUMENT Disclosure . . . . . . . . . . 739

D. ANALYSIS OF THE ALBERTA ENERGY AND UTILITIES

BOARD'S POSITION ON DOCUMENT DISCLOSURE . . . . . . 740

B.A., LL.B. (Toronto); LL.M. (Yale). Ms. Woolley practices in the areas of regulatory law and litigation in the Calgary office of Heenan Blaikie LLP. 


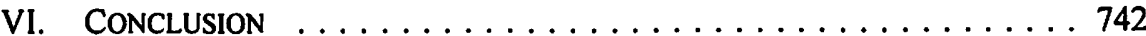

\section{INTRODUCTION}

The content of administrative law's requirements of procedural fairness and natural justice are not easily reduced to set principles. Courts only reluctantly make concrete statements about what is required for a proceeding to be fair, preferring the position that "the requirements of natural justice must depend on the circumstances of each particular case and the subject matter under consideration."

The attitude of the courts in this respect is both consistent and desirable given the judicial and legislative recognition of the important and unique role to be played by administrative bodies in the modern state, and the concomitant adoption by the courts of a position of judicial deference to administrative decision-making. As the Supreme Court of Canada has said,

It must not be forgotten that every administrative body is the master of its own procedure and need not assume the trappings of a court. The object is not to import into administrative proceedings the rigidity of all the requirements of natural justice that must be observed by a court, but rather to allow administrative bodies to work out a system that is flexible, adapted to their needs and fair. ${ }^{2}$

Having said that, starting in 1978, when the Supreme Court issued its seminal judgment in Re Nicholson and Haldimand-Norfolk Regional Board of Commissioners of Police, ${ }^{3}$ courts and legislatures have increasingly recognized the existence of minimum procedural requirements which will apply to any administrative proceeding that has the potential to affect the legal rights or fundamental interests of the parties affected by it: namely, that the person whose rights or interests may be affected be informed of the case against him or her and be given the opportunity to meet it. ${ }^{4}$

Prior to the decision of the Supreme Court of Canada in Stinchcombe v. The Queen ${ }^{5}$ there was no judicial or legislative recognition that those basic procedural safeguards included a right of document discovery and/or a broad right of disclosure. ${ }^{6}$ It was

$1 \quad$ Re Nicholson and Haldimand-Norfolk Regional Board of Commissioners of Police (1978), 88 D.L.R. (3d) 671 at 681 (S.C.C.) [hereinafter Nicholson], citing Russel v. Duke of Norfolk, [1949] 1 All E.R. 109 at 118.

$2 \quad$ Knight v. Indian Head School Division No. 19 (1990), 69 D.L.R. (4th) 489 at 512 (S.C.C.). See also Baker v. Canada (Minister of Citizenship and Immigration) (1999), 174 D.L.R. (4th) 193 at 210-11 (S.C.C.).

Nicholson, supra note 1.

See my discussion of document disclosure and procedural faimess pre-Stinchcombe below, Part III.

(1991), 68 C.C.C. (3d) 1 [hereinafter Stinchcombe].

"Prior to the decision of the Supreme Court of Canada in Stinchcombe and the amendments to Ontario's Statutory Powers Procedure Act, no obligation existed to provide full disclosure of the evidence intended to be introduced in administrative proceedings to other parties." D.J. Brown \& J.M. Evans, Judicial Review of Administrative Action in Canada (Toronto: Canvasback Publishing, 1997) at 9.53 [footnotes omitted]. This paper does not review the statutory movement towards greater disclosure such as the Statutory Powers Procedure Act, R.S.O. 1990, c. S-22 [hereinafter 
recognized in the case law that it was of central importance to procedural fairness that administrators disclose the basis on which the administrator intends to make his or her decision. However, the case law did not address or recognize the issue of whether a person was entitled to broader rights of discovery and/or disclosure of documents from another party. ${ }^{?}$

The decision of the Supreme Court in Stinchcombe, and the relationship between document discovery and procedural fairness articulated in that decision, have had a significant impact on judicial and legislative understanding of the importance of document discovery to procedural fairness in administrative decision-making. Since Stinchcombe, courts and legislatures appear to be increasingly cognizant of the importance of document discovery to procedural fairness and natural justice.

The application of the Stinchcombe standard has, however, been neither complete nor unanimous. The vast majority of the cases which have adopted the Stinchcombe principles in favour of document disclosure arise in the context of human rights and professional disciplinary proceedings; there is as yet no broader articulation of the need for the application of Stinchcombe principles in all administrative proceedings which are on the "judicial" end of the procedural spectrum. Further, many courts seem reluctant to embrace a standard adopted in a criminal proceeding - where the most traditional model of the adversary system is recognized as appropriate - in the administrative law context where the goal has been procedural flexibility and efficiency.

Finally, those cases which have considered the application of the Stinchcombe principle have exclusively addressed the issue of document production where the

SPPA]. It is noted, however, that Alberta's Administrative Procedures Act, R.S.A. 2000, c. A-3, does not have a provision equivalent to s. 5.4(1) of the SPPA. It is also noted that Stinchcombe, and in particular Sopinka J.'s identification in that case of the relationship between document discovery and procedural fairness, is not only useful for determining whether in an individual case disclosure is adequate (as is done in the post-Stinchcombe administrative law cases) but is also useful for determining the adequacy of statutory disclosure/discovery requirements. The final section of this article, which considers the statutory framework of the Alberta Energy and Utilities Board, attempts such an analysis.

7 There is an important distinction between disclosure of information which an "administrative agency acquires ... either pursuant to its statutory powers or as a result of its accumulated knowledge" (Brown \& Evans, ibid. at 9.60) and disclosure from a party appearing before an administrative agency; the latter category is referred to here as "document discovery." Stinchcombe's significance for administrative law relates to the second category of disclosure rather than the first, and this article will not address the extensive case law which sets out an administrative agency's duty of disclosure. It should be noted, however, that this distinction is complicated by the fact that in some cases administrative agencies stand, in effect, in the position of an opposing party. This is the case where an administrative agency has a litigation function (e.g., a human rights commission which litigates matters before a human rights tribunal). Disclosure from those agencies in the course of their conduct of their adversarial function closely parallels disclosure by a party, and will be addressed here. In fact, a central concern of the administrative law cases which rely on Stinchcombe to order further disclosure is the issue of disclosure by administrative agencies acting in a quasi-adversarial role. For an overview of the two categories of disclosure see Brown \& Evans, ibid., "Disclosure of Evidence By a Party," c. 9.6 and "Disclosure of Evidence by the Administrative Agency," c. 9.7. 
documents in question are already in the hands of an administrative body. No cases have considered whether, and to what extent, Stinchcombe should apply where the documents in question are in the possession of a party which is not a government agency. ${ }^{8}$

In this article I will briefly review the pre-Stinchcombe administrative law cases on procedural fairness and document disclosure; identify the significance for administrative proceedings of Sopinka J.'s analysis in Stinchcombe of the importance of document discovery to procedural fairness; review the case law which has considered the application of Stinchcombe to administrative law proceedings; and, finally, consider the application of Stinchcombe to administrative proceedings before the Alberta Energy and Utilities Board (AEUB). The AEUB is worth considering because it has recently adopted Rules of Practice ${ }^{9}$ which, like the jurisprudence, reflect the increasing but incomplete recognition of the need for document discovery in administrative proceedings. The AEUB's Rules of Practice provide a model for consideration of whether the limited document disclosure they contemplate creates an appropriate balance between procedural fairness and orderly and efficient decision-making by administrative tribunals. In addition, at the AEUB the central issue is not with respect to the production of documents from the tribunal, but is rather with respect to the production of documents from a private party appearing before the tribunal. The AEUB is not unusual in this respect; many administrative bodies involve matters where the key documentary records are likely to be in the possession of a party to the proceeding rather than in the possession of the administrative agency. The AEUB provides an example for consideration of the issue of whether, and to what extent, procedural fairness requires that parties to a proceeding be given a right to document discovery from another participant in a proceeding, and the impact the imposition of such a requirement would have on the efficiency and operation of an administrative tribunal.

\section{Document Disclosure and Procedural fairness Pre-Stinchcombe}

The jurisprudence with respect to the requirements of procedural fairness prior to the Supreme Court's decision in Stinchcombe is remarkably silent on the issue of the requirement for disclosure of relevant documents in the possession of another party to that proceeding. Despite its central role in civil litigation, there is no indication that, prior to Stinchcombe, document discovery was a part of the regulatory process for

* The administrative body possessing the documents in each of the cases relying on Stinchcombe to order disclosure was, in effect, a party to the proceeding. However, there is still a distinction between the appropriate disclosure obligations for an administrator who is effectively a party and a private individual (whether corporate or personal) who is a party. The Stinchcombe cases do not address this distinction.

$9 \quad$ Alta. Reg. 101/2001. 
administrative decision-makers, ${ }^{10}$ or that the absence of document discovery was an issue brought before the courts for review.

That is not to say, however, that the issue of disclosure was not considered by the courts. In fact, the issue of the adequacy of disclosure to persons affected by administrative decision-making had been an issue for the Supreme Court since Nicholson. The issue was not the ability of a party to access documents in the possession of another party which might be relevant and helpful to his or her case, but was rather with the ability of a party to have sufficient information to allow him or her to know the case he or she had to meet and the materials to be relied upon by the administrator in rendering the decision.

This requirement sometimes fell within the general requirement for "notice," and sometimes fell within the general requirement that an administrator cannot hear evidence in the absence of a party, but in either case is recognizable as being fundamentally about the need for disclosure in order to achieve procedural fairness:

[T]he post-Nicholson jurisprudence does have at least one clear message for even judicial or quasijudicial tribunals. The broadening of the scope of the situations to which implied procedural protections attach has caused judges to reflect somewhat more on the essence of natural justice, and what has emerged from this has been a heightened emphasis on disclosure of the proposed grounds for action and of the relevant evidence as being virtually the sine qua non of any notion of procedural fairness. ${ }^{11}$

This aspect of the requirement for disclosure is apparent in a number of Supreme Court decisions prior to Stinchcombe. In Nicholson, the Court held that the problem with the Police Board's decision was that it had not disclosed to Nicholson the reasons "why his services were no longer required." 12 In Singh v. Canada (Minister of Employment and Immigration) ${ }^{13}$ the Court found that it was inconsistent with the requirements of fundamental justice that a refugee claimant be required to present his case to the Immigration Appeal Board without disclosure of the. information relied upon by the Minister in rejecting his refugee claim. ${ }^{14}$ In Cardinal and Oswald v. Director of Kent Institution, ${ }^{15}$ the decision of the Director of Kent Institution was held to be contrary

See supra note 6. Many administrative bodies include in their procedure (and did so prior to Stinchcombe) an interrogatory process through which a party is asked written questions on the application or evidence which they have filed. Through this process documents are often provided; however, this process does not amount to a requirement that a party produce all relevant documents. Document production is incidental, not central, to the process. Further, the extent of the documents produced depends entirely on the nature and quality of the questions asked. Where a party is unaware of the existence of a relevant document he or she will not necessarily ask a question which will generate the production of that document. in N. Finkelstein \& B. MacLeod Rogers, eds., Recent Developments in Administrative Law, (Toronto: Carswell, 1987) at 21 [emphasis added]. 
to the requirements of procedural fairness because he did not disclose to the inmates "why the Director did not intend to act in accordance with the recommendation of the board." In Syndicat des employes de production du Quebec et de l'Acadie v. Canadian Human Rights Commission, ${ }^{17}$ the Court held that the procedural requirements imposed on the Human Rights Commission at the investigative stage included the requirement that the Commission disclose to the parties "the substance of the evidence obtained by the investigator and which was put before the Commission."18 In Knight v. Indian Head School Division No. 19, ${ }^{19}$ the Court held that the School Division was required to disclose to Knight the reasons for his dismissal. ${ }^{20}$

Finally, in Kane v. University of British Columbia ${ }^{21}$ the Court held that it was improper for an administrator to issue a decision on the basis of evidence (in this case oral testimony) which had not been provided to the party affected by the decision:

It is a cardinal principle of our law that, unless expressly or by necessary implication, empowered to act ex parte, an appellate authority must not ... hear evidence in the absence of a party whose conduct is impugned and under scrutiny. Such party must, in the words of Lord Denning ... "know the case which is made against him. He must know what evidence has been given and what statements have been made affecting him: and then he must be given a fair opportunity to correct or contradict them." 22

The emphasis on disclosure in these cases, while distinguishable from the disclosure required by the Supreme Court in Stinchcombe, or that associated with document discovery in the civil litigation process, is significant for an analysis of the role Stinchcombe disclosure may play in ensuring procedural fairness. These cases indicate that the elimination of surprise, ensuring that a participant in an administrative proceeding is fully informed of the case he has to meet, and ensuring that he is provided with a proper opportunity to meet that case, have always been important to the Supreme Court's identification of what procedural fairness requires. To the extent that Stinchcombe disclosure is related to or furthers the same or similar goals, its imposition on administrative tribunals is no more than a natural evolution of the preStinchcombe administrative law decisions.

On the other hand, the requirement that an administrative body disclose the information on which it intends to rely in making a decision is arguably closer to the core of procedural faimess than is the requirement that an opposing party provide disclosure. Without the first kind of disclosure, the party affected by the proceeding cannot in any way address the allegations made against it. Further, the administrator's decision is less likely to be accurate or fair if it relies on allegations and/or materials

17 (1989), 62 D.L.R. (4th) 385 (S.C.C.) [hereinafter Syndicat des employes].

is lbid. at 430.

1. Knight, supra note 2.

(1) Ibid. at 512 .

$\because \quad$ (1980), 110 D.L.R. (3d) 311 (S.C.C.) [hereinafter Kane].

$\because \quad$ Ibid. at 322 . 
which have not been challenged or addressed by a party who is almost certain to have information with respect to those allegations/materials.

Both of these defects in procedural fairness can also be argued to arise from a failure to disclose all relevant documents by an opposing party. If there are relevant documents in the possession of one party which would help another party's case, the lack of access to those documents both undermines the latter party's ability to litigate effectively and has the potential to decrease the accuracy and fairness of the administrator's decision. However, there is arguably a lower likelihood of unfairness arising from the failure to disclose documents which are not before the administrator and/or are not being considered by the administrator in rendering his or her decision.

The question which must be answered is, "Are the risks to procedural faimess from not requiring document discovery significant enough to warrant the introduction of document discovery into administrative proceedings and, if so, in which administrative proceedings should document discovery be required?" The administrative law cases prior to Stinchcombe neither answer nor address this question; the analysis in Stinchcombe squarely raises the issue of whether procedural fairness is achievable in an administrative proceeding absent full document discovery.

\section{STINCHCOMBE}

While the ruling in Stinchcombe that s. 7 of the Canadian Charter of Rights and Freedoms $^{23}$ requires that when prosecuting indictable offences the Crown must disclose all relevant documents to the defence, subject to a reviewable claim for privilege, does not apply to administrative proceedings, the reasons provided by the Court for that ruling, and in particular its analysis of the importance of document discovery to ensuring the fairness and justice of criminal proceedings, are both helpful and significant for the analysis of the requirements of procedural fairness and natural justice in administrative proceedings. ${ }^{24}$

The Court's analysis centred on the practical and philosophical justification for document discovery. First, the Court noted that document discovery has long been accepted as part of civil litigation on the basis that justice is better served by the elimination of surprise and by parties being prepared to "address issues on the basis of complete information of the case to be met." Second, the Court stated that where the Court has information or evidence, that information or evidence is "the property of the public," not the property of the Crown. ${ }^{26}$ Third, the Court found that the evidence indicated that time would in fact be saved by greater disclosure and that, overall, the

Part I of the Constitution Act, 1982, being Schedule B to the Canada Act 1982 (U.K.), 1982. c. 11.

24 As discussed infra note 30 and accompanying text, since it is this aspect of Stinchcombe which has significance for administrative law, rather than its delineation of the requirements of $s$. 7 of the Charter for Crown Counsel prosecuting indictable offences, the fact that Stinchcombe is a Charter decision has not undermined its application to administrative law.

25 Stinchcombe, supra note 5 at 6.

$26 \quad$ lbid. at 7. 
workload of the Crown would be reduced. Finally, the Court held that "the search for truth is advanced rather than retarded by disclosure of all relevant material" and that "failure to disclose impedes the ability of the accused to make full answer and defence." 27

All of these justifications for requiring disclosure in criminal proceedings support, at a conceptual level, the position that procedural fairness in administrative proceedings would also be enhanced by allowing for document discovery. If the elimination of surprise and ensuring that parties are prepared to address issues on the basis of complete information ensures that justice is done, and if document discovery is necessary to eliminate surprise and ensure that the parties have complete information, document discovery must be a necessary component of justice. While it may not be the case that in all administrative proceedings "justice" is the applicable standard ${ }^{28}$ the recognition that document discovery is necessary to ensure that justice is done suggests that document discovery may be necessary to ensure procedural fairness in administrative proceedings approaching the judicial end of the administrative spectrum.

Further, the conclusion that the disclosure of documents advances the search for truth supports the position that the disclosure of documents is a necessary component of procedural fairness and natural justice. While administrative efficiency is a worthy goal, it seems difficult to argue that in circumstances where the effect of an administrative decision on a person is significant, the administrative body should not adopt a process consistent with advancing the search for truth.

Finally, given administrative law's existing recognition of the importance of giving a person the opportunity to present argument and evidence with respect to the case against them, Stinchcombe's assertion that document disclosure is a necessary component of a person's ability to make full answer and defence may suggest that document disclosure is necessary to ensure that a person has a proper opportunity to present argument and evidence with respect to the case against them. ${ }^{29}$

In sum, if justice is better served, the search for truth advanced, and a person's ability to make full answer and defence protected by allowing parties to have complete information of the case they have to meet, denying parties access to complete information obtained through document discovery cannot seriously be argued as being consistent with the requirements of procedural fairness and natural justice.

Ibid. at 8-9.

28 See, e.g., Martineau v. Matsqui Institution Disciplinary Board (No. 2) (1979), 106 D.L.R. (3d) 385 at 411 (S.C.C.) per Dickson J. (as he then was), dissenting.

29 It is acknowledged that "full answer and defence" has a particular significance for criminal law. However, it is submitted that the concept is sufficiently analogous to administrative law's concern with giving a party affected by a proceeding the opportunity to present argument and evidence with respect to the case against them, to support the position that if discovery is necessary to allow a person to make full answer and defence it would also assist a person in presenting argument and evidence with respect to the case against them. 
This raises, however, a central difficulty with the analysis of procedural fairness in administrative law. It is accepted that administrative decision-makers are required to be fair. It is also accepted that it is not, in most cases, necessary for administrative decision-makers to adopt the full trappings of a court. However, it is rare for courts to offer an analysis of why processes viewed as essential to ensuring procedural fairness in civil or criminal litigation can be dispensed with in an administrative proceeding without compromising the fairness of that proceeding. For example, it is trite to observe that the strict rules of evidence dealing with matters such as hearsay and similar fact evidence will not be followed in administrative tribunals. It is rare, however, to find any analysis explaining why these concepts are necessary to ensure a just outcome in a court proceeding but have no place in an administrative tribunal. That they are unnecessary is accepted, but the reasons why are not addressed. ${ }^{30}$

The answer may be that courts themselves do not entirely accept that some of these matters are necessary in ensuring procedural fairness. This is particularly so with respect to the technical rules of evidence where, in civil proceedings, it is not unusual to see latitude granted by the Court with respect to admissibility and the conduct of examination of witnesses. In light of the Court's analysis in Stinchcombe, however, it would be difficult to maintain that documentary disclosure can be avoided on this basis. Stinchcombe is unambiguous in its assertion that document discovery is necessary for procedural fairness.

Alternatively, it may be that courts view the overarching public good of the efficient operation of the administrative state as outweighing the decrease in fairness resulting from a less rigid process in administrative proceedings. This view would be consistent with the Supreme Court's position that there is a spectrum of procedural fairness, with legislative or policy-orientated decisions requiring less procedural safeguards than those approaching the judicial end of the spectrum. ${ }^{31}$ In cases where the effect of the decision is more societal than personal, the need for efficient and effective administrative decision-making can plausibly outweigh the need to adhere to strict procedural safeguards. On the other hand, where the decision is, like civil or criminal litigation, directed at the rights or fundamental interests of the individual, the efficient and effective operation of the administrative state does not provide a compelling justification for abandoning the procedural safeguards associated with litigation. the context of administrative tribunals; however, it is significant that none of the key Supreme Court cases on procedural fairness analyze this issue.

" Martineau, supra note 28 at 410 per Dickson J. (as he then was), dissenting. See also Knight, supra note 2 at 510-11: "the concept of fairness is entrenched in the principles governing our legal system and the closeness of the administrative process to the judicial process should indicate how much of those governing principles should be imported into the realm of administrative decisionmaking" [citations omitted]; and Brown \& Evans, supra note 6 at 7.11: "Accordingly, courts will now be more likely to consider the probable costs and benefits of a particular procedural right, taking into account such factors as the nature of the issue to be decided, the impact of the decision on the individual, the caseload of the agency, and the identity and structure of the decision-making body." 
Once this method of analyzing when procedural safeguards from civil and/or criminal litigation should be adopted in administrative proceedings is accepted, however, the question becomes not if Stinchcombe disclosure is necessary to procedural fairness the terms of the Court's analysis demonstrates that it is so - but in what circumstances it can nonetheless be dispensed with in order to further the broader public good.

\section{Application of Stinchcombe in administrative LaW Proceedings}

\section{A. Key CASES}

Perhaps because of the clear relationship between the rationale for requiring disclosure in Stinchcombe and the requirements of procedural faimess, the Supreme Court's decision has had a remarkable and somewhat surprising influence on the development of administrative law. Surprising because although courts recognize the origins of procedural fairness in the "principles governing our legal system," 32 it is rare in administrative law decisions to see courts directly incorporate cases and concepts from civil procedure, let alone a case and concept developed in the criminal context. Furthermore, the actual decision in Stinchcombe relied on s. 7 of the Charter. While the Charter can apply to administrative law proceedings, ${ }^{33}$ it does not always, and none of the cases that relied on Stinchcombe in support of disclosure discussed the Charter. ${ }^{34}$

The first and most frequently cited of the cases incorporating the Stinchcombe standard into administrative law is Ontario (Human Rights Commission) v. Ontario (Board of Inquiry into Northwestern General Hospital). ${ }^{35}$ In that case the Board of

Knight, ibid. at 510-11.

For a discussion of the role of s. 7 outside of criminal law, see Blencoe v. British Columbia (Human Rights Commission), [2000] 2 S.C.R. 307 [hereinafter Blencoe]; Winnipeg Child and Family Services (Central Area) v. W.(K.L.) (2000), 191 D.L.R. (4th) I (S.C.C.); New Brunswick (Minister of Health and Community Services) v. G.(J.), [1999] 3 S.C.R. 46; Alberla Treasury Branches v. Leahy (2000), 270 A.R. 1 (Q.B.), aff'd without reasons [2002] A.J. No. 524 (C.A.), online: QL (AJ).

In my view, the fact that Stinchcombe is a Charter decision has not impacted the reliance on the decision in administrative law because it is not the result of Stinchcombe that is significant for administrative law. Administrative law gains no insight from the fact that $\mathbf{s} .7$ requires disclosure from the Crown in prosecuting indictable offences. Rather, it is Sopinka J.'s analysis of the importance of disclosure in civil proceedings and for ensuring accurate and fair decision-making - an analysis which is in no way confined to the Charter - which is significant for administrative law. Indeed, as discussed below, it is this aspect of Stinchcombe which has been relied upon by those courts using Stinchcombe in support of an order for further disclosure. It may also be significant that in Stinchcombe itself disclosure is not viewed as a new requirement introduced by the Charter, but is rather identified as "a wholly natural evolution of the law in favour of disclosure by the Crown of all relevant material" (Stinchcombe, supra note 5 at 10). The Charler is also identified as reflecting the values of the common law: "The common law has acquired new vigour by virtue of its inclusion in 5.7 of the Canadian Charter of Rights and Freedoms as one of the principles of fundamental justice" (Stinchcombe, ibid. at 9). The downplaying of the importance of the Charter to the outcome in Stinchcombe may also increase the comfort of judges in administrative law cases relying on the decision.

(1993), 115 D.L.R. (4th) 279 (Ont. Div. Ct.) [hereinafter House]. 
Inquiry was investigating allegations of racial and ethnic discrimination against the Northwestern General Hospital. In furtherance of its investigation, and in reliance on Stinchcombe, it had ordered the Human Rights Commission to produce "all statements made by the Complainants to the Commission and its investigators at the investigation stage." The Human Rights Commission challenged the production order on the basis that Stinchcombe had no application to a human rights proceeding, and that the documents were subject to public-interest privilege.

The Divisional Court upheld the Board's production order. The Court relied on Stinchcombe and, in particular, on the relationship set out in that case between document disclosure and procedural fairness:

It is in our view significant that in civil proceedings the "full discovery of documents and oral examination of parties and even witnesses are familiar features of the practice." The important principle enunciated by Mr. Justice Sopinka is that "justice was better served when the element of surprise was eliminated from the trial and the parties were prepared to address issues on the basis of complete information of the case to be met". It does not take a quantum leap to come to the conclusion that in the appropriate case. justice will be better served in proceedings under the Human Rights Code when there is complete information available to the respondents. ${ }^{36}$

The Court also held, although it did not rely on this conclusion for its decision, that the role of "commission counsel is analogous to that of the Crown in criminal proceedings," ${ }^{37}$ with the result that the decision in Stinchcombe that the obligation of counsel is to bring forward all credible relevant evidence, rather than to obtain a conviction, applies in the human rights context.

A similar approach to House was taken by the court in Markandey v. Ontario (Board of Ophthalmic Dispensers). ${ }^{38}$ In that case the court considered whether, in its conduct of disciplinary proceedings, it was inappropriate for the Board of Ophthalmic dispensers not to have disclosed, prior to or during the proceeding, information with respect to an undercover investigation of Markandey. The Court held that the disclosure was not adequate, and endorsed a high standard of disclosure to ensure the fairness of disciplinary proceedings before an administrative tribunal:

The importance of full disclosure to the faimess of the disciplinary proceedings before the Board cannot be overstated. Although the standard of pre-trial disclosure in criminal matters would generally be higher than in administrative matters ... tribunals should disclose all information relevant to the conduct of the case, whether it be damaging to or supportive of a respondent's position, in a timely manner unless it is privileged as a matter of law. Minimally, this should include copies of all witness statements and notes of the investigators. The disclosure should be made by counsel to the Board after a diligent review of the course of the investigation. Where information is withheld on the basis of its irrelevance or a claim of legal privilege, counsel should facilitate review of these decisions, if necessary. The absence of a request for disclosure, whether it be for additional disclosure or otherwise.

3. [1994] O.J. No. 484 (Gen. Div.), online: QL (OJ). 
is of no significance. The obligation to make disclosure is a continuing one. The Board has a positive obligation to ensure the faimess of its own processes. The failure to make proper disclosure impacts significantly on the appearances of justice and the fairness of the hearing itself. Seldom will relief not be granted for a failure to make proper disclosure. ${ }^{39}$

In the result, the court held that the lack of disclosure had been cured by full disclosure made in preparation for the appeal, which was a trial de novo.

The approach of the courts in House and Markandey was approved of in the dissenting judgment of Laskin J.A. in Howe v. Institute of Chartered Accountants of Ontario. ${ }^{40}$ In that case Howe, an accountant subject to disciplinary proceedings, sought to compel the Institute to produce the report of an accountant retained by the Institute's Professional Conduct Committee to investigate allegations made against Howe. The majority of the Court of Appeal refused to consider Howe's application on the basis that it was premature. Justice Laskin disagreed with the prematurity argument and considered the disclosure issue. Like the Divisional Court in House, Laskin J.A. concluded that the analysis of the Supreme Court in Stinchcombe as to the importance of document disclosure for procedural fairness applies to disciplinary proceedings before a regulatory tribunal:

Stinchcombe concerned the disclosure obligations of the Crown in indictable offences, not the disclosure obligations of administrative tribunals, and Sopinka J. indicated that many of the factors that he canvassed may not apply at all, or apply with less force even to other kinds of criminal offences. In this sense, the chair of the Discipline Committee was literally correct in stating that Stinchcombe does not apply to professional regulatory proceedings. But several of the observations made by Sopinka $J$. in that case seem apt to determine the content of the fairness obligations of administrative tribunals. Thus, it is hardly surprising that many courts have already applied a number of the principles underlying the decision in Stinchcombe to administrative proceedings. ${ }^{41}$

Justice Laskin noted that disciplinary proceedings are at the "judicial end of the spectrum," and that since the Institute's proceedings did not provide for document discovery it was especially important to ensure that there was proper disclosure. ${ }^{42} \mathrm{He}$ also noted pre-Stinchombe administrative law principles in favour of full disclosure. Justice Laskin concluded that, based on Stinchcombe and these factors, the Institute's duty to act fairly required disclosure of the expert report.

While the analysis in Howe is significant insofar as it relies on Stinchcombe as a basis for its order and appears to approve of the approach taken by the courts in House and Markandey, it is arguable that the reliance on Stinchcombe in that decision was ultimately unnecessary. The disclosure at issue was not of relevant documents not before the administrator, or those not to be considered by the administrator, but was rather disclosure of documents before the decision-maker which would almost certainly

\footnotetext{
Ibid. at para. 43.

(1994), 118 D.L.R. (4th) 129 (Ont. C.A.).

lbid. at 142-43 [emphasis added].

Ibid. at 142.
} 
be a factor in his decision. As discussed earlier, the necessity for procedural faimess of disclosure of documents which are going to be considered by the administrative decision-maker was recognized by the Supreme Court in many administrative decisions prior to Stinchcombe; the issue raised by Stinchcombe was whether such disclosure is sufficient for procedural fairness, or whether broader rights of document discovery are required. $^{43}$

Stinchcombe was also relied on to support disclosure of information before the administrative decision-maker in Williams v. Canada (Regional Transfer Board) ${ }^{44}$ In Williams, the Federal Court of Appeal held that it was improper for a prison transfer decision to be made without disclosing to the inmate materials before the decisionmaker which may be relied upon in making the decision. The Court relied upon the Supreme Court's decision in Stinchcombe:

In my view, there are some circumstances in which procedural fairness will require that an administrative authority disclose and make available to the person concerned all material which may be in the authority's possession and which may arguably have a bearing for or against a decision which it is proposed to make regarding such person. This duty is at its highest and most developed in the criminal process, where the Supreme Court has recently confirmed in unambiguous terms the duty of the prosecution to disclose to the accused all material in its possession whether or not the Crown proposes to use such material.

While I would not wish to be understood as holding that the rules governing prosecutions should be imported without distinction into the procedures relating to the transfer of penitentiary inmates, I am nonetheless of the view that, in the particular circumstances of this case, the requirement [for disclosure] of a progress summary in the hands of the decision-maker was an essential component of procedural faimess. $^{45}$

As noted, it is not clear that it was necessary for the courts in these cases to rely on Stinchcombe in considering whether the non-disclosure was inconsistent with the requirements of procedural fairness. That the courts nonetheless did so affirms the significance for administrative law of Stinchcombe's analysis of the relationship between procedural fairness and disclosure. Moreover, as indicated by House and Markandey, other decisions have relied on Stinchcombe to address the issue of document discovery. In Alberta Human Rights and Citizenship Commission v. Alberta Motor Association ${ }^{46}$ the Alberta Provincial Court considered an application by the Commission to compel the Alberta Motor Association (AMA) to answer inquiries about alleged discrimination. The AMA had declined to have its employees interviewed by the Commission when the Commission refused to provide the AMA with a document prepared by the

On this topic more generally see Brown \& Evans, supra note 6, at 9.61: "The general rule is that if such information [acquired by an administrative agency pursuant to its statutory powers or as a result of its accumulated knowledge] is to be relied upon, it must be disclosed unless it is confidential and the likely harm that would result from disclosure outweighs that resulting from non-disclosure, or unless it is in some other way privileged."

lbid. at 722 .

(1998), A.R. 310 (Prov. Ct. (Civ. Div.)). 
complainant setting out her specific allegations concerning the alleged discrimination. The Court rejected the Commission's application. Judge Donnelly held that in failing to disclose to the AMA the complete information it had received from the complainant, the Commission "did not act fairly towards the respondent. ${ }^{177}$ With respect to the duty of disclosure the Court held:

The question of what information a respondent or complainant is entitled to from Boards or Commissions performing functions similar to those being performed by the applicant, has been the subject of considerable litigation. The answers given in that litigation have varied according to the circumstances of each case such as the applicable legislation, what information is being sought and the stage at which it is being sought. However, as a general rule, in answering this question it is appropriate to apply the principle enunciated by Sopinka, J., in $R$. v. Stinchcombe that justice is better served when the parties are prepared to address issues on the basis of complete information of the case to be met. 48

Similarly, in Barnes v. Alberta Teachers' Association, ${ }^{49}$ the Alberta Court of Queen's Bench ordered further disclosure in disciplinary proceedings brought against a teacher for unprofessional conduct. The Court held that the entire investigative file should be provided to counsel for the teacher in order to permit him to assess the case he had to meet before the Discipline Committee. The Court stated:

While the concept of full disclosure, or the Stinchcombe case, as it is well known in criminal law, may not necessarily apply entirely to matters such as this, it appears to me to be appropriate in this case to allow the Applicant and the Applicant's counsel full access to the investigative file against Ms. Barnes. $^{\text {so }}$

In Hammami v. College of Physicians and Surgeons of British Columbia, ${ }^{\text {s1 }}$ the B.C. Supreme Court held that the College had acted improperly in failing to disclose its entire file with respect to Dr. Hammami. The Court did so on the basis that Stinchcombe, and the administrative cases following it, support the position that,

where the decision of an administrative law tribunal might terminate or restrict the "accused's" right to practice or pursue that career or seriously impact on a professional reputation then the principles in Stinchcombe, in respect of disclosure may well apply. ${ }^{52}$

The Court also relied on the College's conduct of its investigation of Dr. Hammami in concluding that "this is the type of case where the principles of Stinchcombe should be applied." 53 
In these cases which have relied upon Stinchcombe as support for the requirement of disclosure to ensure procedural fairness, the courts have generally avoided making blanket assertions as to the applicability of Stinchcombe to administrative law proceedings, often noting that a judgment arising from criminal proceedings can only tangentially apply in the administrative law context. This discomfort with applying criminal law principles to administrative law cases is more obvious in those cases where the courts have declined to order Stinchcombe disclosure. Thus, in a successor to the 1997 Hammami decision, in which Hammami challenged the College's decision to decline to disclose certain documents on the basis of privilege and confidentiality, the Court held that the disclosure given by the College was sufficient, and appeared to retreat from the broad disclosure mandated by the 1997 Hammami decision:

I am not prepared to find that Dr. Hammami is entitled to a full blown disclosure pursuant to the principles of Stinchcombe such as would be the case if he was charged with a criminal offence

In my view, Dr. Hammami should be aware of those types of communications to allow him an understanding of the ground rules applicable to such hearings. To ensure a level playing field, there should be such disclosure of a limited nature. ${ }^{54}$

A similar reluctance to incorporate Stinchcombe into the requirements of procedural fairness is apparent in the judgment of the Federal Court in Ciba-Geigy Canada v. Canada (Patented Medicine Prices Review Board). ${ }^{55}$ In that case Ciba-Geigy sought disclosure from the Board of all documents in the Board's possession relating to matters in the hearing, particularly the report on which the Chairman acted in ordering the hearing. The Federal Court Trial Division affirmed the Board's refusal to grant such exhaustive disclosure. In particular, the Court rejected the application of Stinchcombe in the context of the Patented Medicine Prices Review Board. The Court noted the decision of the Ontario Court of Appeal in House, but found that there is a significant distinction between the review of the prices of patented medicines and human rights litigation, noting that "[t]ribunals charged with regulating economic activity have not had placed on them the same high standards as tribunals dealing with personal individual rights." 56 The Court held that the Review Board had properly exercised its discretion in balancing its duty of fairness to the applicant with the need for it to discharge its responsibilities in the public interest on an ongoing basis. In conclusion, the Court stated:

In summary, when the statutory scheme of this Board is looked at, the Board is a regulatory board or tribunal. There is no point in the legislature creating a regulatory tribunal if the tribunal is treated as a criminal court. The obligations concerning disclosure imposed by the doctrine of fairness and natural justice are met if the subject of the inquiry is advised of the case it has to meet and is provided with all the documents that will be relied on. CIBA has been provided with much more than the minimum disclosure required to enable it to meet the case. Law and policy require that some leeway be given 
an administrative tribunal with economic regulatory functions, if, in pursuing its mandate, the tribunal is required by necessity to receive confidential information. It is not intended that proceedings before these tribunals be as adversarial as proceedings before a court. To require the Board to disclose all possibly relevant information gathered while fulfilling its regulatory obligations would unduly impede its work from an administrative viewpoint. Fairness is always a matter of balancing diverse interests. I find that fairness does not require the disclosure of the fruits of the investigation in this matter. ${ }^{57}$

The Court of Appeal affirmed the trial decision, noting in particular McKeown J.'s conclusion that "the administrative tribunal here has economic regulatory functions and has no power to affect human rights in a way akin to criminal proceedings." 58

Ciba-Geigy was followed by the Federal Court of Appeal in D\& B Companies of Canada v. Canada (Director of Investigation and Research). ${ }^{59}$ The primary issue in that case was with respect to the refusal of the Director of Investigation and Research to produce certain documents on the basis of public interest privilege. In challenging the Director's position the appellant relied on Stinchcombe. The Court ruled that Stinchcombe had no application to proceedings before the Competition Tribunal:

\begin{abstract}
Stinchcombe does require very broad disclosure by the Crown in indictable offences. But it does not purport to lay down identical requirements for civil cases or even for summary conviction offences. Nor does it require that privileged information be disclosed. Indeed, the main thrust of Stinchcombe is to require that the Crown in prosecution of indictable offences make disclosure similar to that available in civil cases. But civil cases have always recognized various forms of privilege. Stinchcombe has not been widely applied in civil cases: I need go no farther than the decision in this court in CibaGeigy ... which held that Stinchcombe does not apply to proceedings before that board. The essential distinction was that a proceeding before such a tribunal does not have the dire consequences for a party as does a prosecution for an indictable offence. The same can be said of a proceeding such as the present one before the Competition Tribunal. The learned presiding judge in my view correctly declined to apply Stinchcombe in this case. ${ }^{60}$
\end{abstract}

Finally, in Kullman v. Calgary (City) Police Commission, the Alberta Court of Queen's Bench refused to apply Stinchcombe to a police disciplinary proceeding, noting that there is "no criminal stigma attached to a disciplinary hearing,"61 and in Nova Scotia (Minister of Community Services) v. D.J.M. the Nova Scotia Supreme Court refused to apply Stinchcombe disclosure to a decision to enter a name in the Child Abuse Register on the basis that "this is not a criminal proceeding and D.J.M. is not an accused person as contemplated by Stinchcombe." 62

3) (1994), 58 C.P.R. (3d) 353 (F.C.A.), leave to appeal to S.C.C. refused (1995), 187 N.R. 320 (S.C.C.) [hereinafter $D \& B$ ].

(1) Ibid. at 357-58.

(1) (1995), 168 A.R. 227 at 230 (Q.B.).

6. (2002). 202 N.S.R. (2d) 82 at para. 44 (N.S. S.C.). 
The final Stinchcombe disclosure cases of note are two cases which apply the postStinchcombe analysis of the Supreme Court in R. v. Dixon ${ }^{63}$ In Dixon the Supreme Court held that a remedy for non-disclosure would only arise subsequent to a proceeding where the accused could demonstrate either that the result of the trial may have been different had the information been disclosed or that the non-disclosure affected the overall fairness of the trial process. The application of this standard in administrative law is problematic, however, as the Supreme Court's position in administrative law cases has been that a breach of procedural fairness constitutes an error of jurisdiction which always invalidates a decision:

I find it necessary to affirm that the denial of a right to a fair hearing must always render a decision invalid, whether or not it may appear to a reviewing court that the hearing would likely have resulted in a different decision. The right to a fair hearing must be regarded as an independent, unqualified right which finds its essential justification in the sense of procedural justice which any person affected by an administrative decision is entitled to have. It is not for a court to deny that right and sense of justice on the basis of speculation as to what the result might have been had there been a hearing. ${ }^{64}$

Nonetheless, in Milner v. Registered Nurses Association of British Columbia ${ }^{65}$ the British Columbia Supreme Court applied the Dixon standard and, after finding that relevant material had not been disclosed, went on to consider whether the nondisclosure prejudiced the ability of the nurse subject to disciplinary proceedings to make full answer and defence, affected the reliability of the result, or affected the overall fairness of the trial process. Ultimately the Court determined that disclosure of the materials themselves would not have produced any different result, but that the nondisclosure did affect the ability of counsel to conduct the hearing, and that a new hearing was required.

In Bailey v. Saskatchewan Registered Nurses' Association, ${ }^{66}$ the Court also applied Dixon. First, the Court rejected the Association's argument that Dixon requires counsel for the defence to exercise due diligence with respect to document disclosure, and that counsel for Bailey had failed to exercise due diligence. The Court held that while such an obligation may exist, it was not breached by counsel for the appellants who never had any knowledge of undisclosed documents, expressly or otherwise, so that they could not reasonably have been expected to have requested disclosure of such documents. Second, the Court held that documents in question were relevant and that the failure to disclose the documents "impacts significantly on the [appearance] of justice and the fairness of the hearing itself. ${ }^{167}$ As a result of this and other procedural irregularities, the Court quashed and set aside the convictions of the appellants, and issued a prohibition order against further proceedings against them. 


\section{B. Significance of the Cases}

The cases which have relied on Stinchcombe to find that document disclosure is a necessary component of procedural fairness arise, with the exception of Williams, in the context of either professional disciplinary proceedings or human rights proceedings. While not putting at issue a person's liberty or security, as a criminal proceeding does, both disciplinary and human rights proceedings address fundamental personal interests and/or rights. ${ }^{68}$ As such, the incorporation of a criminal disclosure standard in those cases can be considered a more natural evolution than the incorporation of such a standard in a proceeding dealing with economic regulation, for example, such as a proceeding before the Competition Tribunal or the Patented Medicine Prices Review Board. This is the case even though it may be that proceedings before those bodies are on the judicial end of the spectrum and require the observance of a rigorous standard of procedural faimess. The narrow frame of application of the cases which apply Stinchcombe may suggest that their reliance on Stinchcombe does not have broader significance to administrative proceedings which do not similarly address fundamental personal interests or rights. It was, of course, this distinction which was relied upon by the Federal Court in Ciba-Geigy and in $D \& B$ in declining to order Stinchcombe disclosure.

On the other hand, it must be remembered that the administrative law decisions prior to Stinchcombe suggest that disclosure of information to persons affected by administrative decisions has always been an important component of procedural fairness, with the result that, as discussed above, the application of Stinchcombe can be understood as simply a natural extension of those earlier decisions. As such, it may be arguable that these cases can and should be precedents applicable to all administrative proceedings at the judicial end of the spectrum. This argument is supported by the fact that in both Howe and Williams Stinchcombe was used in circumstances not dissimilar to those administrative law cases decided prior to Stinchcombe in which the lack of disclosure was found to violate procedural fairness - that is, Stinchcombe was used in Howe and Williams to do something administrative law decisions were already doing. Further, in Howe Laskin J.A. linked his decision to the pre-Stinchcombe administrative cases.

Despite this latter argument, I suggest that it is unlikely that, outside of administrative proceedings which are concerned with fundamental personal interests or rights, courts are going to require full document discovery or disclosure. First, the cases are not uniform in their willingness to adopt Stinchcombe, and the cases which have declined to do so indicate clearly the courts' discomfort with relying on a criminal law standard in administrative law. Second, in the cases which found the non-disclosure to be objectionable, the courts were ambiguous in their reliance on Stinchcombe, and expressly qualified the relevance of that decision for administrative law (for example,

ax Williams, which involved a federal prison transfer arising from an alleged violation of prison rules, also clearly involved fundamental personal interests and/or rights. See Blencoe, supra note 33 for a discussion of the distinction between criminal and human rights proceedings in the context of s. 7 of the Charter. 
Barnes and Hammami). In general, the cases relied on the principles set out in the decision respecting the importance of document disclosure for procedural fairness, rather than on the ruling in the case that greater disclosure was required than had been provided by the Crown. Third, even if Stinchcombe were to be adopted wholeheartedly, that does not diminish the fundamental administrative law principle that courts must defer to administrative decision-makers, and that administrative bodies are masters of their own procedure.

Thus, if a reasonable effort is made to ensure that parties are aware of the case before the administrative decision-maker, the fact that not every relevant document is provided to those parties will likely be countenanced in order to ensure the effective operation of the administrative state. In fact, even in decisions which affect fundamental personal interests or rights, if a reasonable but limited approach to disclosure is adopted by a decision-maker, and it appears that parties have been treated fairly and consistently with that approach, it is unlikely that courts will interfere. Such non-interference is consistent with the deference courts have afforded administrative tribunals in making them masters of their own procedure.

The question with which courts must be concerned, however, is when should the approach of an administrative decision-maker be considered unreasonable? The postStinchcombe cases demonstrate that, in answering this question, while Stinchcombe may not technically apply, and while the broad disclosure contemplated by that decision may not be necessary for procedural fairness in administrative proceedings, the fundamental relationship between document disclosure and procedural fairness articulated in that decision should be taken into account in determining what constitutes reasonable disclosure. As discussed above, Sopinka J.'s decision may address criminal procedure, but it clearly sets out why providing parties with full document disclosure increases the likelihood of accurate and fair decisions. The decisions of the Federal Court of Appeal in both Ciba-Geigy and $D \& B$ distinguish Stinchcombe on the easy basis that it deals with indictable offences and is therefore irrelevant to administrative law. Neither decision explains, however, why the principles in favour of disclosure set out by Sopinka J. are irrelevant to the determination of what is necessary to ensure procedural fairness. Nor does either decision acknowledge that, in general, it is these principles that have been relied upon as supporting greater disclosure in the administrative law context. A failure to take those principles into account in determining what constitutes reasonable disclosure will likely result in insufficient disclosure being ordered, and in parties before administrative tribunals being inhibited in their ability to participate in the process, and to fully answer and defend the case against them. How this analysis could take place will be considered in the next section in the context of the Alberta Energy and Utilities Board's adoption of new Rules of Practice, which broaden the Board's prior approach to disclosure but still offer relatively limited document disclosure and/or pretrial disclosure to parties.

The post-Stinchcombe cases also do not clearly resolve the issue of disclosure of documents from parties to the administrative proceeding who are not an administrative agency or body. In all of the post-Stinchcombe administrative law cases, the documents were in the possession of an administrative body at the time disclosure was sought. It 
is not uncommon in administrative proceedings, however, for most, if not all of the relevant documents to be in the possession of parties which are not administrative agencies. Those documents may be obtained by an administrative body through an investigative process, but if the proceeding is not investigatory (for example, it involves an application by a party for regulatory approval of a particular course of conduct, such as constructing a pipeline) then the documents may not be obtained unless they are volunteered by the party or come to light through an interrogatory process.

Much of the rationale for document disclosure set out by Sopinka J. in the Stinchcombe decision applies equally to the disclosure of documents from parties to the proceeding who are not an administrative agency. The example of the approach taken in civil proceedings clearly contemplates discovery from other parties to a proceeding. Further, ensuring accurate and fair decisions, and that a party is able to make full answer and defence, are no less enhanced by obtaining all relevant documents from another party than obtaining relevant documents from an administrative body.

On the other hand, the special obligations placed on Crown counsel do not have any bearing on the conduct of a third-party before an administrative tribunal, and Sopinka J. was careful to limit the scope of his analysis to the obligations of Crown counsel without speaking to the obligations which could arguably exist for defence counsel.

On the whole, and although not specifically addressed by the post-Stinchcombe administrative law cases, the logical conclusion of the application of Stinchcombe in the administrative law context would be to require the production of relevant documents from third parties. Justice Sopinka's reliance on the precedent of civil proceedings, in which such documents are required to be produced, and on disclosure's importance for ensuring accurate and fair decisions, supports such a result.

In each of the cases which decided in favour of the application of Stinchcombe, and ordered that documents be disclosed, the administrative body could be said to have been acting as a de facto party to the proceeding. In disciplinary proceedings prosecuted by a profession's governing body, in human rights proceedings and in prison disciplinary cases, the matter is prosecuted by the administrative body who, as a result, effectively occupies the position of a party. While there are certain obvious distinctions between an administrative body acting as a de facto party and a private party ${ }^{69}$ it can be argued that it follows from the courts' use of Stinchcombe to require disclosure from administrative bodies who are de facto parties that Stinchcombe should also be used to require disclosure from non-administrative bodies.

It is not clear, however, that this use of Stinchcombe to require full document discovery is consistent with the efficient operation of the administrative state. In a proceeding involving many parties, adopting broad, and broadly applicable, disclosure obligations could result in administrative proceedings becoming even more lengthy, cumbersome and paper-intensive than they already are. As discussed above, it is legally 
relevant in determining the content of the requirements of procedural fairness that the administrative state needs to function effectively and efficiently, as well as fairly.

Finally, the two cases which rely on the decision of the Supreme Court in Dixon as a basis for determining whether the breach of procedural fairness is material must be noted. I suggest that the reliance on Dixon in these cases is simply in error. Stinchcombe's usefulness arises not from the determination made by the Supreme Court in that case with respect to the obligations of disclosure of the Crown when proceeding with indictable offences. Rather, Stinchcombe is useful because in the course of making that determination the Supreme Court set out foundational principles which indicate the relationship between document disclosure and procedural fairness. Similarly, while Dixon may articulate principles of use in administrative law, ${ }^{70}$ the determination in that case as to what the result of a failure to disclose in a criminal proceeding should be has no relevance to administrative law. Thus, to rely on the approach taken in Dixon for determining whether the failure to disclose should result in a new proceeding in an administrative law case is equivalent to relying on the determination in Stinchcombe that disclosure is necessary when proceeding with indictable offences, rather than relying on the underlying principles in that case. The Supreme Court of Canada decided in Cardinal what the result of a breach of procedural fairness in administrative law cases should be - the analysis of the Supreme Court as to what the result of a lack of disclosure in a criminal case should be does not, it is submitted, have the authority to reverse that decision.

\section{Document Disclosure in Proceedings Before the ALBERTA ENERGY AND UTILITIES BOARD}

\section{A. The Alberta Energy and Utilities BoARd}

The Alberta Energy and Utilities Board was formed in 1994 through the merger of the Public Utilities Board (PUB) and the Energy Resources and Conservation Board (ERCB). The PUB was responsible for the supervision of gas, water and electric utilities in Alberta and was, in particular, concerned with the oversight of the rates charged to Alberta consumers by those utilities. The PUB's jurisdiction arose from the Public Utilities Board $A c t^{71}$ and the Gas Utilities $A c t,{ }^{72}$ among others. The ERCB was responsible for the regulatory oversight of facilities applications in Alberta, such as gas-well licensing and intra-Alberta pipelines, and exercised its authority pursuant to the Energy Resources Conservation Board Act, ${ }^{73}$ the Pipeline Act, ${ }^{74}$ and the Oil and Gas Act ${ }^{75}$ among others. The Alberta Energy and Utilities Board Act $^{76}$ gave the AEUB the power previously exercised by the PUB and the ERCB. Subsequently, when

Although it is not apparent to me what those might be.

R.S.A. 2000, c. P-45.

R.S.A. 2000 , c. G-5.

R.S.A. 2000 , c. E-10.

R.S.A. 2000 , c. P-15.

R.S.A. 2000 , c. O-6.

R.S.A. 2000 , c. A-17. 
the Alberta government enacted the Electric Utilities $A c t^{77}$ in 1995, the AEUB was also given the authority to supervise the deregulation of electricity in Alberta. The AEUB thus exercises broad jurisdiction over the energy sector in Alberta, not dissimilar to that exercised nationally by the National Energy Board.

\section{B. Document Disclosure Issues Raised by Proceedings BEFORE THE ALBERTA ENERGY AND UTILITIES BOARD}

The appropriate scope of document disclosure is a significant issue before the AEUB. In both utilities and facilities applications there is a serious disparity between the extensive and complete information, knowledge and relevant documents possessed by applicants, whether utilities seeking approval of rates or companies seeking approval of the construction of a facility, and the limited and incomplete information and knowledge possessed by intervenors. This gap gives applicants the ability to tailor the information presented to the Board, and to enhance the likelihood that their application will be approved. In order to narrow that gap, and to ensure that the adjudicative process before the AEUB is a complete and accurate one, it is important that applicants be required to provide broad information to allow the Board and intervenors to test and challenge the application.

On the other hand, as with all administrative bodies, processes before the AEUB are intended to be efficient and less cumbersome than a judicial proceeding. Introducing broad requirements for document discovery, particularly given the nature of the issues before the AEUB in which innumerable documents could be "relevant" but not particularly probative or helpful, ${ }^{78}$ could result in proceedings radically removed from any semblance of efficiency. In addition, the imposition of broad requirements of document disclosure on applicants could result in similarly broad disclosure requirements being placed on intervenors. Such a requirement could discourage participation in regulatory proceedings, especially by municipalities or corporations who may have competitive or other concerns arising from the production of such information. Since such parties are often in the best financial position to intervene, and to test the application being brought forward by the applicants, it is unlikely to be in the public interest to discourage the participation of those parties.

The challenge for the AEUB is, therefore, ensuring that there is sufficient production to diminish or eliminate the information advantage of applicants, while also ensuring an efficient procedure in which other parties are not discouraged from participating.

7w For example, a forecast included in a general rate application for operating and maintenance expenses could have hundreds and thousands of accounting records which are "relevant" to it. 


\section{The Alberta ENERgy AND Utilities BoARD'S POSITION ON DOCUMENT DISClosure}

Until recently, the disclosure obligations placed on participants before the AEUB were, at least in theory, very limited in scope. The ERCB Rules of Practice ${ }^{79}$ contained no specific rules regarding production, although they did grant the Board residual power to issue directions about the conduct of a hearing. The PUB's Rules of Practice $^{80}$ were somewhat broader, although still relatively narrow in scope. In essence, the Rules gave parties the right to request the production of documents, but the only consequence for a failure to produce the documents was that they could not be used in the hearing, or that secondary evidence of the content of the documents could be provided:

14. Either party shall be entitled, at any time, before or at the hearing of the case, to give notice in writing to the other party to produce any book, document or writing in his possession, custody or control relating to the matters in question, for the inspection of the party giving such notice, or his solicitor, and to permit him to take copies thereof; and any party not complying with such notice shall not afterwards be at liberty to put such documents in evidence on his behalf in said proceedings, unless he satisfy the Board that he had sufficient cause for not complying with such notice.

15. Either party may give the other notice in writing to produce at the hearing such documents as relate to any matter in difference (specifying the said documents) and which are in the possession or control of such other party; and if such notice be not complied with, secondary evidence of the contents of the said documents may be given by or on behalf of the party who gave such notice.

Over time, however, the obligations of production placed on parties before the EUB and its predecessor Boards became more significant than these rules would suggest. There were two main avenues for document disclosure. First, documents provided to the Board were provided to all interested parties unless the Board had some basis for keeping the documents confidential. Second, and more significantly, the interrogatory process used in proceedings before the Board became a major source of document disclosure. Intervenors were permitted to ask questions of an applicant and, while the applicant could decline to answer the question, the Board was in some cases prepared to order that the information requested be provided.

It was the case, however, that participants in a proceeding had no clear basis on which to request that the Board order the production of documents from an applicant. In addition, applicants, and those intervenors who filed evidence and were subject to interrogatories, had no clear direction from the Board as to the information required to be provided in support of an application or evidence.

The lack of formality in the AEUB's approach to disclosure, and the uncertainty surrounding what could be required, were addressed in 2001 through the enactment, pursuant to the Alberta Energy and Utilities Board Act, ${ }^{81}$ of new Rules of Practice. ${ }^{82}$ 
The Rules formalize the practice that, subject to claims of confidentiality, all documents filed with the Board must be placed in the public record. In addition, the Rules give the Board the clear authority to order the production of all relevant and material documents, and give the Board the power to adjourn an application, or dismiss it, if production does not take place in accordance with the Rules:

12(1) Subject to this section, all documents filed in respect of a proceeding must be placed on the public record.

(2) If a party wishes to keep confidential any information in a document, the party may, before filing the document, file a request for confidentiality and serve a copy of the request on the other parties

16(1) Unless the Board otherwise directs, if a party intends to present documentary evidence at an oral hearing or electronic hearing, or is directed to do so by the Board, the party shall file the documentary evidence and serve a copy of it on the other parties before the hearing takes place

(3) If a party is not able to file all of the party's documentary evidence before the hearing takes place, the party shall

(a) file such documentary evidence as is available at that time, and

(b) file a statement

(i) identifying the balance of the documentary evidence to be filed, and

(ii) stating when the balance of the documentary evidence will be filed.

(4) If a party is not willing to file documentary evidence when directed to do so by the Board under subsection (1) the party shall file a statement setting out the reasons why the party is not willing to do so.

17(1) The Board may direct the applicant or an intervener to file such further information, documents or material as the Board considers necessary to permit a full and satisfactory understanding of an issue in a proceeding.

(2) If the applicant or the intervener does not file the information, documents or material when directed to do so by the Board under subsection (1), the Board may

(a) adjourn the proceeding until the information, documents or material is filed, or

(b) dismiss the application or submission, as the case may be.

Whether these rules are consistent with the principles in favour of disclosure established in Stinchcombe, and whether they strike an appropriate balance between those principles and the need for an efficient and effective regulatory process, will be addressed in the following section.

\section{ANalysis of the AEUB's Position on Document Disclosure}

There is no question that the AEUB's new Rules of Practice are significantly closer to satisfying the principles in favour of disclosure established by Stinchcombe than was its previous approach. Unlike the PUB's Rules of Practice, the new Rules do not leave the ability to control the information presented to the Board in the hands of the parties appearing before it. The disclosure contemplated by the new Rules is, however, 
significantly less onerous than the scope of disclosure contemplated by the Court in Stinchcombe.

The new Rules place no positive obligation of disclosure on any party appearing before the Board. That is, the new Rules do not require a party to provide the Board with all information, documents or records in its possession which are relevant and material to the proceeding. Rather, the new Rules require only that parties produce additional information if the Board determines that such information is "necessary to permit a full and satisfactory understanding" ${ }^{83}$ of an issue raised by the proceeding, and requests that it be produced. This approach to disclosure is significantly less onerous than that usually followed in civil proceedings, which is the model cited as an example by Sopinka J. in Stinchcombe.

The more important question, however, is whether the new Rules of Practice are consistent with the key principles relating disclosure to procedural fairness set out in Stinchcombe. That is, do the new Rules of Practice provide disclosure sufficient to advance the search for truth and to give parties the ability to make full answer and defence with respect to the issues in the proceeding. This latter principle can, in administrative law, perhaps be more accurately expressed as ensuring that parties have information sufficient to understand the case they have to meet and to give them an adequate opportunity to meet that case.

Without taking into account the need to balance these principles with the need to ensure effective and efficient administrative proceedings, it is not clear that the new Rules are adequate to satisfy the principles of procedural fairness. In particular, it is not clear that the failure of the Rules to place any positive obligation on a party to produce all relevant and material documents with respect to the application or evidence which they have filed is consistent with the requirements of procedural fairness. The problem is that the Board's ability to determine whether additional information is required is subject to influence by parties, and particularly applicants, appearing before it. For example, if an applicant in a facilities approval proceeding knows that it has documents in its possession which cast doubt upon its emissions forecasts, but it has other documents which support its forecasts, it can simply produce those documents in support, indicate to the Board that the documents provide an adequate basis for determining whether or not the forecast is accurate, and omit to mention or produce the unfavourable documents. The Board would have no way of knowing that documents which cast doubt on the forecast exist and have not been presented; it is left to chance that the Board will make a request for information which will result in the disclosure of the unfavourable documents. ${ }^{84}$

$3 \quad$ Ibid., r. 17(1).

s An interested party could ask for an interrogatory which would, if fully responded to, produce the document. However, if the party of whom the request is made did not produce the document it would still require an order of the Board for production to occur. Further, an interested party's interrogatory is, like the Board's order under $r .17$, constrained by the information deficit of the interested party relative to the party of whom the request is being made. 
When the need to ensure an effective and efficient administrative process is taken into account, however, the new Rules appear much closer to the requirements of procedural fairness. To place a positive obligation on parties to produce all relevant documents would make processes before the Board even more overwhelmingly document-intensive than they are now. A typical proceeding before the Board under the current rules involves tens of thousands of pages of information and documents; broader disclosure obligations could raise that number to the hundreds of thousands without, in many cases, having any positive effect on the resolution of the material issues before the Board. This does not eliminate the problem identified earlier with respect to the potential ability of parties before the Board to successfully hide relevant but unhelpful documents, but it does provide a countervailing concern which, as administrators, the Board is required to address.

The adequacy of the new Rules ultimately depends on the Board taking a rigorous approach to the application of those Rules. If materials are provided which do not give the Board or interested parties the necessary information to have a full and satisfactory understanding of an issue in a proceeding then the Board must exercise its authority under $r$. 17. The Board must also be willing to grant general requests for documentation in appropriate cases, such as where the issue is very significant for the public interest and/or the Board's discharge of its statutory mandate. A failure by the Board to rigorously apply the new Rules will undermine the ability of those Rules and the exercise of the authority which they give, to satisfy the requirements of procedural faimess.

Overall, the new Rules reflect an attempt by the AEUB to grapple with the issue raised by Stinchcombe and the administrative law cases following it: what level of disclosure is necessary to ensure procedural fairness? To some extent the effectiveness of the new Rules in addressing this issue must be left to a case in which the issue squarely arises; however, it is clear from the foregoing that the principles set out in Stinchcombe provide an appropriate starting point for the analysis of the effectiveness of the new Rules. This is not to commit the fallacy of saying that Stinchcombe applies to administrative law, or that it cannot be applied without consideration of the realities and goals of administrative procedures, but is to say that the foundational principles articulated in that case should not be disregarded in identifying the requirements of procedural fairness.

\section{Conclusion}

Stinchcombe matters for administrative law. Cases have not universally applied it, and those that have done so have not always appreciated the essential relevance of the case, which arises not from its determination that Crown counsel in that case did not disclose enough, but rather from the relationship which Sopinka J. articulated between document discovery and procedural fairness. Administrative tribunals, and courts which review their actions, must determine a fair process given a pragmatic and functional analysis of what the administrative tribunal was given the authority to do. In making that determination the importance of disclosure to further the search for truth, increase the accuracy of decision-making, and ensure that parties know the case they have to meet and have a fair opportunity to do so, should not be disregarded. 